\title{
C9orf72 repeat expansion does not affect the phenotype in primary progressive aphasia
}

Marjut Haapanen $^{\mathrm{a}}$, Kasper Katisko ${ }^{\mathrm{a}}$, Tuomo Hänninen ${ }^{\mathrm{b}}$, Johanna Krüger ${ }^{\text {dee }}$, Päivi

Hartikainen $^{\mathrm{b}}$, Annakaisa Haapasalo ${ }^{\mathrm{c}}$, Anne M Remes $^{\mathrm{a}, \mathrm{b}, \mathrm{d}, \mathrm{e}}$, Eino Solje $^{\mathrm{a}, \mathrm{b} *}$

Keywords: Primary progressive aphasia, frontotemporal dementia, frontotemporal lobar degeneration, $C 9$ orf72

${ }^{\mathrm{a} I n s t i t u t e}$ of Clinical Medicine - Neurology, University of Eastern Finland, Kuopio, Finland.

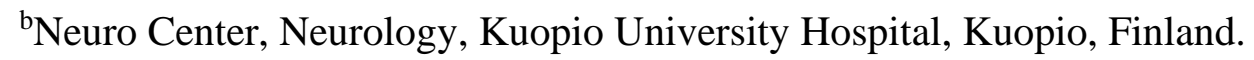

${ }^{\mathrm{c}}$ A.I. Virtanen Institute for Molecular Sciences, University of Eastern Finland, Kuopio, Finland.

${ }^{\mathrm{d}}$ Research Unit of Clinical Neuroscience, Neurology, University of Oulu, Oulu, Finland. ${ }^{\mathrm{e}} \mathrm{MRC}$, Oulu University Hospital, Oulu, Finland.

*Corresponding author

Eino Solje, MD, PhD

University of Eastern Finland - Institute of Clinical Medicine, Neurology

P.O. Box 1627 (Yliopistonranta 1C) FI-70211 Kuopio, Finland

$+358408425553$

eino.solje@uef.fi 


\begin{abstract}
Primary progressive aphasia (PPA) forms the spectrum of language variants of frontotemporal lobar degeneration (FTLD), including three subtypes each consisting of distinctive speech and language features. Repeat expansion in C9orf72 gene is the most common genetic cause of FTLD. However, thus far only little is known about the effects of the $C 9$ orf72 repeat expansion on the phenotype of PPA. This retrospective study aimed at determining the differences between the PPA phenotypes of the C9orf72 expansion carriers and non-carriers. Our results demonstrated no significant differences between these groups, indicating that the C9orf 72 repeat expansion does not substantially affect the phenotype of PPA.
\end{abstract}




\section{INTRODUCTION}

The language variants of frontotemporal lobar degeneration (FTLD), known as primary progressive aphasias (PPA), are a group of neurodegenerative diseases affecting particularly speech and language skills [1]. PPA includes three main variants - nonfluent (nfvPPA), semantic (svPPA) and logopenic (lvPPA) aphasia. NfvPPA is the most common subtype representing approximately $25 \%$ of the FTLD cases and characterized by agrammatism in language production [1,2]. In svPPA, the main features are anomia and difficulties in singleword comprehension and the phenotype is present in $20-25 \%$ of the FTLD patients $[1,2]$. The lvPPA is the rarest subtype of the PPA phenotypes, characterized by language deficit influencing word retrieval and sentence repetition [1]. Approximately 17\% of PPA patients have lvPPA as the main phenotype [3]. Neuropathologically the nfvPPA and svPPA are typically associated with the FTLD-type brain pathology, whereas the lvPPA variant is more often associated with Alzheimer`s disease-like pathology [4].

Repeat expansion in C9orf72 gene is considered as the most common genetic cause of FTLD [5,6]. In general, the $C 9$ orf72 repeat expansion is associated with the behavioral variant frontotemporal dementia (bvFTD) subtype or with FTLD with motor neuron disease, whereas it is estimated to be only a rare cause of pure PPA (approx. 1-6\%) [7-9]. In the case of bvFTD, the $C 9$ orf72 repeat expansion has been reported to associate with psychiatric phenotypes, especially psychosis [10-12]. However, whether the C9orf72 repeat expansion influences the phenotype of PPA patients still needs further research [13-16].

Consequently, the present retrospective study aimed at assessing differences in the clinical phenotype of the C9orf72 repeat expansion carriers and non-carriers with PPA. Considering the rareness of these disorders, demographic information is also demonstrated. 


\section{MATERIALS AND METHODS}

The study population consists of PPA patients with confirmed C9orf72 repeat expansion status diagnosed at the Kuopio University Hospital between the years 1996 to 2016 . The data were collected retrospectively from the patient records including information about demographics, symptoms, clinical examinations, neuropsychological assessment, speech-language pathology assessment, laboratory analyses, and neuroimaging from 18 patients. Speech and language skills were evaluated with Western Aphasia Battery (WAB) and neuropsychological skills with The Consortium to Establish a Registry for Alzheimer's disease neuropsychological battery (CERAD-NB).

The diagnoses were made retrospectively based on the classification of primary progressive aphasia and its variants [1]. The limit for the pathologically expanded C9orf72 repeat was set at $>30$ repeats [6]. Other FTLD-associated genes were not screened, because our previous studies have shown that these mutations are extremely rare in the Finnish population, likely due to the genetic isolation of the Finns [17-19].

Statistical analyses were performed with SPSS statistics 25 software and significance level was set at $\mathrm{p}<0.05$. Continuous variables were compared with Mann-Whitney-U test and categorial variables with Fisher`s exact test due to the small sample size and non-parametric distribution of continuous variables.

\section{RESULTS}

The demographic data of the study groups is demonstrated in the Table 1. The C9orf72 repeat expansion carriers and non-carriers did not significantly vary in terms of sex, years of education, age at onset, age at diagnosis, and/or disease duration from onset of symptoms. 
Within the $C 9$ orf72 repeat expansion carriers, the mean disease duration (time from onset to death) was slightly lower than within the non-carriers but the difference was not statistically significant. (Table 1).

A total of five patients were $C 9$ orf 72 repeat expansion carriers and 13 were non-carriers (Table 1). All of the 13 non-carriers met the clinical criteria for nfvPPA [1]. Within the C9orf72 repeat expansion carriers, three participants fulfilled the clinical criteria for nfvPPA, and two did not meet the whole criteria explicitly for any PPA variant according to the patient records from the symptom onset to death. These patients, however, fulfilled the inclusion criteria for PPA according to Mesulam 2001 and were classified as PPA not otherwise specified (PPA-NOS). The two patients displaying PPA-NOS showed progressive language symptoms and both of them had impaired comprehension of syntactically complex sentences and word-finding difficulties. The patients did not have apraxia of speech or agrammatism and therefore they were not classified as nfvPPA. One of the patients had hallucinations as the first symptom and presented executive dysfunction at the diagnostic phase. The two PPA-NOS patients showed agitation and wandering after the diagnosis and they also had abnormal gag reflex at the late stage of the disease. Later on, one of the patients displayed also hyperorality, personality changes, and extrapyramidal symptoms (rigidity and hypo/bradykinesia).

All of the 18 PPA patients of the study cohort had neuroimaging results suggestive for PPA in the magnetic resonance imaging (MRI) or computed tomography of the brain (CT) of the brain, single photon emission computed tomography (SPECT)/ or fluorodeoxyglucose positron emission tomography (FDG-PET), thus resulting in a total of 16 nfvPPA and two PPA-NOS diagnoses, which were supported by imaging according to the current criteria $[1,20]$. More 
detailed clinical characteristics of the patients and the distribution of the diagnoses supported by the imaging findings are presented in Table 2 .

There were no statistically significant differences in the phenotype according to the clinical criteria of nfvPPA between the C9orf72 repeat expansion carriers and non-carriers at the time of diagnostic phase. All of the 18 participants had spared single-word comprehension and object knowledge at the time of the diagnosis. Moreover, apraxia of speech and impaired comprehension of syntactically complex sentences were the most common symptoms in the clinical criteria. (Table 2).

The first symptoms of the PPA patients with a known C9orf72 repeat expansion status are presented in Table 2. Both in the C9orf72 repeat expansion carrier and in the non-carrier groups the most common initial symptom was word-finding difficulties (40\% and $38.5 \%$, respectively). Memory impairment and hallucinations were more common first symptoms among the $C 9$ orf 72 repeat expansion carriers, whereas among the non-carriers more diffuse symptoms as dizziness or collapses, fatigue and overall slowness as well as depression, apathy or inertia were also present. In total, there were no statistically significant differences between the repeat expansion carriers and non-carriers regarding the first symptoms.

At the time of the diagnostic phase, all of the $C 9$ orf 72 repeat expansion carriers and non-carriers had word-finding difficulties (Table 2). Furthermore, other language symptoms in addition to those listed in the clinical criteria of nfvPPA were poverty of speech, reading difficulties, writing difficulties and dysarthria. One non-carrier with dysarthria had nfvPPA and ALS. 
A subset of non-carriers had also slowness of speech, impaired word repetition and mutism and these symptoms were not seen among the $C 9$ orf 72 repeat expansion carriers. Nonetheless, there were no statistically significant differences among the carriers and non-carriers in the initial language symptoms.

The Consortium to Establish a Registry for Alzheimer's disease neuropsychological battery (CERAD-NB) is a standardized test battery commonly used as a screening tool for detecting memory diseases [21,22]. All subtest scores for both groups were below the cutoff values indicating cognitive impairment [23]. However, the subtest scores of CERAD-NB did not show statistically significant differences between the C9orf72 repeat expansion carriers and noncarriers (Table 3). Verbal fluency and MMSE scores were lower in C9orf72 repeat expansion carriers than in non-carriers, however the difference was not statistically significant between the groups.

We did not detect prominent differences in psychiatric features in the $C 9$ orf 72 repeat expansion carriers compared to non-carriers. Hallucinations were a first symptom for one carrier and one non-carrier had hallucinations at the time of the diagnostic phase. As for depression, one noncarrier had depression as a first symptom.

\section{DISCUSSION}

Here, we analyzed the language features and demographic characteristics of PPA patients with and without the $C 9$ orf72 repeat expansion. Although $C 9$ orf72 repeat expansions are rare in patients with PPA (approx. 1-6\% in other cohorts [7-9]), we found that a considerable percentage $(28 \%)$ of the patients in the present Finnish PPA cohort were expansion carriers, likely reflecting the high prevalence of the C9orf72 repeat expansion in Finland in general 
[6,24]. The main findings of the present study reveal that there may not be statistically significant or clinically relevant differences in the demographics, language symptoms or in the CERAD- test battery performance between the C9orf72 repeat expansion carriers and noncarriers. Notably, disease duration, verbal fluency and MMSE scores were slightly lower in the carriers, but the results were not statistically significant. Additionally, cognitive deficits were detected in all subtests of the CERAD-NB among nfvPPA patients showed, indicating that the phenotype of PPA among the C9orf72 repeat expansion carriers and non-carriers is not exclusively limited to language deficits.

Word-finding difficulty was the most common first symptom among the PPA participants despite the genetic background. In addition, the most common features of speech in general were apraxia of speech and impaired comprehension of syntactically complex sentences when regarding the prevailing clinical criteria of nfvPPA.

Studies related to bvFTD have indicated different phenotypes between the C9orf72 repeat expansion carriers and non-carriers, with especially psychotic symptoms being more prevalent in patients with the $C 9$ orf 72 repeat expansion $[10,12,25]$. In the present study the phenotypes between the repeat expansion carriers and non-carriers did not show differences in PPA patients. Regarding the linguistic symptoms in bvFTD patients, a prior study showed lower scores in verbal fluency [26]. Accordingly, our present study found a trend towards more severely impaired verbal fluency also in PPA patients with the $C 9$ orf72 repeat expansion, but with the limited cohort size, the difference was statistically non-significant.

Word-finding difficulty is one of the first symptoms of PPA $[27,28]$ and it was found to be the most common first symptom also in the present study. A recent meta-analysis demonstrated signs of agrammatism or apraxia of speech in a majority of nfvPPA participants however there 
has been a substantial variation in the prevalence of dysarthria among nfvPPA patients in different studies $(18 \%-60 \%)$ [29]. Similarly, in our study, apraxia of speech was a frequently documented symptom $(66.7 \%)$ and the prevalence of dysarthria was low (11.1\%).

According to the review by Rohrer and colleagues, patients with PPA who carried the $C 9$ orf 72 repeat expansion had predominantly the nfvPPA clinical syndrome, whereas the other two subtypes (svPPA and lvPPA) were rare among these carriers [16]. On the other hand, the study by Galimberti and colleagues described two patients with the svPPA syndrome in their cohort of 29 C9orf72 repeat expansion carriers, without any patients with the nfvPPA phenotype [14]. In our study none of the patients had svPPA or lvPPA. Thus, these data altogether suggest that the nfvPPA is the most common PPA clinical phenotype in the C9orf72 repeat expansion carriers, whereas the $C 9$ orf 72 repeat expansion-associated svPPA is rare.

The main strength of this study is the careful and thorough examination of all the patients at the neurological outpatient clinic by experienced neurologists. The limitations are the nature of the retrospective study and a small cohort group of PPA patients. However, PPA caused by the C9orf72 repeat expansion is rare, and our study provides the largest characterization of the C9orf72 repeat expansion-associated PPA so far. The comparisons between the groups, however, should be interpreted with caution, as there is a possibility of false negative results due to the limited statistical power. We did not further adjust the statistical analyses for multiple comparisons, as the initial analyses revealed no significant differences between the groups (i.e. adjusting for the risk of false positive was not relevant).

In conclusion, the findings of this study suggest that the $C 9$ orf 72 repeat expansion does not significantly affect the phenotype in PPA. Future studies with larger well-characterized patient cohorts are needed to evaluate the impact of the C9orf72 repeat expansion in PPA further. 
Considering the rareness of the C9orf72 repeat expansion-associated PPA, international collaboration is needed to obtain larger cohorts in the future.

\section{ACKNOWLEDGEMENTS}

This project was supported by Finnish Medical Foundation, Finnish Cultural Foundation, Maire Taponen Foundation, Maud Kuistila Memorial Foundation, Olvi-Foundation, The University of Oulu Scholarship Foundation and Academy of Finland (no. 315459 and 315460). This study is part of the FinFTD network research activities.

\section{CONFLICTS OF INTEREST}

The authors have no conflict of interest to report.

\section{REFERENCES}

[1] Gorno-Tempini ML, Hillis AE, Weintraub S, Kertesz A, Mendez M, Cappa SF, Ogar JM, Rohrer JD, Black S, Boeve BF, Manes F, Dronkers NF, Vandenberghe R, Rascovsky K, Patterson K, Miller BI, Knopman DS, Hodges JR, Mesulam MM, Grossman M (2011) Classification of primary progressive aphasia and its variants. Neurology 76, 1006-1014.

[2] Hernandez I, Fernandez M-V, Boada M, Ruiz A (2018) Frontotemporal Lobar Degeneration (FTLD): Review and Update for Clinical Neurologists. Curr Alzheimer Res 15, 511-530.

[3] Grossman M (2010) Primary progressive aphasia: clinicopathological correlations. Nat Rev Neurol 6, 88-97.

[4] Mesulam M, Wicklund A, Johnson N, Rogalski E, Léger GC, Rademaker A, Weintraub S, Bigio EH (2008) Alzheimer and Frontotemporal Pathology in Subsets of Primary Progressive Aphasia. Ann Neurol 63, 709-719.

[5] DeJesus-Hernandez M, Mackenzie IR, Boeve BF, Boxer AL, Baker M, Rutherford NJ, Nicholson AM, Finch NA, Gilmer HF, Adamson J, Kouri N, Wojtas A, Sengdy P, Hsiung GYR, Karydas A, Seeley WW, Josephs KA, Coppola G, Geschwind DH, Wszolek ZK, Feldman H, Knopman D, Petersen R, Miller BL, Dickson D, Boylan K, Graff-Radford N, Rademakers R (2011) Expanded GGGGCC hexanucleotide repeat in noncoding region of C9ORF72 causes chromosome 9p-linked FTD and ALS. Neuron 72, 245-256.

[6] Renton AE, Majounie E, Waite A, Simón-Sánchez J, Rollinson S, Gibbs JR, Schymick JC, Laaksovirta H, van Swieten JC, Myllykangas L, Kalimo H, Paetau A, Abramzon Y, 
Remes AM, Kaganovich A, Scholz SW, Duckworth J, Ding J, Harmer DW, Hernandez DG, Johnson JO, Mok K, Ryten M, Trabzuni D, Guerreiro RJ, Orrell RW, Neal J, Murray A, Pearson J, Jansen IE, Sondervan D, Seelaar H, Blake D, Young K, Halliwell N, Callister JB, Toulson G, Richardson A, Gerhard A, Snowden J, Mann D, Neary D, Nalls MA, Peuralinna T, Jansson L, Isoviita VM, Kaivorinne AL, Hölttä-Vuori M, Ikonen E, Sulkava R, Benatar M, Wuu J, Chiò A, Restagno G, Borghero G, Sabatelli M; ITALSGEN Consortium, Heckerman D, Rogaeva E, Zinman L, Rothstein JD, Sendtner M, Drepper C, Eichler EE, Alkan C, Abdullaev Z, Pack SD, Dutra A, Pak E, Hardy J, Singleton A, Williams NM, Heutink P, Pickering-Brown S, Morris HR, Tienari PJ, Traynor BJ (2011) A hexanucleotide repeat expansion in C9ORF72 is the cause of chromosome 9p21-linked ALS-FTD. Neuron 20, 257-268.

[7] Le Ber I, Camuzat A, Guillot-Noel L, Hannequin D, Lacomblez L, Golfier V, Puel M, Martinaud O, Deramecourt V, Rivaud-Pechoux S, Millecamps S, Vercelletto M, Couratier P, Sellal F, Pasquier F, Salachas F, Thomas-Antérion C, Didic M, Pariente J, Seilhean D, Ruberg M, Wargon I, Blanc F, Camu W, Michel B-M, Berger E, Sauvée M, Thauvin-Robinet C, Mondon K, Tournier-Lasserve E, Goizet C, Fleury M, Viennet G, Verpillat P, Meininger V, Duyckaerts C, Dubois B, Brice A, the French research network on FTLD/FTLD-ALS (2013) C9ORF72 Repeat Expansions in the Frontotemporal Dementias Spectrum of Diseases: A Flow-chart for Genetic Testing. $J$ Alzheimer's Dis 34, 485-499.

[8] Flanagan EP, Baker MC, Perkerson RB, Duffy JR, Strand EA, Whitwell JL, Machulda MM, Rademakers R, Josephs KA (2015) Dominant Frontotemporal Dementia Mutations in 140 Cases of Primary Progressive Aphasia and Speech Apraxia. Dement Geriatr Cogn Disord 39, 281-286.

[9] Ramos EM, Dokuru DR, Van Berlo V, Wojta K, Wang Q, Huang AY, Miller ZA, Karydas AM, Bigio EH, Rogalski E, Weintraub S, Rader B, Miller BL, Gorno-Tempini ML, Mesulam MM, Coppola G (2019) Genetic screen in a large series of patients with primary progressive aphasia. Alzheimers Dement 15, 553-560.

[10] Snowden JS, Rollinson S, Thompson JC, Harris JM, Stopford CL, Richardson AMT, Jones M, Gerhard A, Davidson YS, Robinson A, Gibbons L, Hu Q, DuPlessis D, Neary D, Mann DMA, Pickering-Brown SM (2012) Distinct clinical and pathological characteristics of frontotemporal dementia associated with C9ORF72 mutations. Brain 135, 693-708.

[11] Devenney E, Hornberger M, Irish M, Mioshi E, Burrell J, Tan R, Kiernan MC, Hodges JR (2014) Frontotemporal dementia associated with the C9ORF72 mutation: a unique clinical profile. JAMA neurology 71, 331-339.

[12] Solje E, Aaltokallio H, Koivumaa-Honkanen H, Suhonen NM, Moilanen V, Kiviharju A, Traynor B, Tienari PJ, Hartikainen P, Remes AM (2015) The phenotype of the C9ORF72 expansion carriers according to revised criteria for bvFTD. PLOS ONE 10, $\mathrm{e} 0131817$.

[13] Simón-Sánchez J, Dopper EGP, Cohn-Hokke PE, Hukema RK, Nicolaou N, Seelaar H, de Graaf JRA, de Koning I, van Schoor NM, Deeg DJH, Smits M, Raaphorst J, van den Berg LH, Schelhaas HJ, de Die-Smulders CEM, Majoor-Krakauer D, Rozemuller AJM, Willemsen R, Pijnenburg YAL, Heutink P, van Swieten JC (2012) The clinical and pathological phenotype of $C 9 O R F 72$ hexanucleotide repeat expansions. Brain 135, 72335.

[14] Galimberti D, Fenoglio C, Serpente M, Villa C, Bonsi R, Arighi A, Fumagalli GG, Del Bo R, Bruni AC, Anfossi M, Clodomiro A, Cupidi C, Nacmias B, Sorbi S, Piaceri I, Bagnoli S, Bessi V, Marcone A, Cerami C, Cappa SF, Filippi M, Agosta F, Magnani G, Comi G, Franceschi M, Rainero I, Giordana MT, Rubino E, Ferrero P, Rogaeva E, 
Xi Z, Confaloni A, Piscopo P, Bruno G, Talarico G, Cagnin A, Clerici F, Dell'Osso B, Comi GP, Altamura AC, Mariani C, Scarpini E (2013) Autosomal dominant frontotemporal lobar degeneration due to the C9ORF72 hexanucleotide repeat expansion: late-onset psychotic clinical presentation. Biol Psychiatry 74, 384-391.

[15] Rohrer JD (2014) The genetics of primary progressive aphasia. Aphasiology 28, 941947.

[16] Rohrer JD, Isaacs AM, Mizielinska S, Mead S, Lashley T, Wray S, Sidle K, Fratta P, Orrell RW , Hardy J, Holton J, Revesz T, Rossor MN, Warren JD (2015) C9orf72 expansions in frontotemporal dementia and amyotrophic lateral sclerosis. Lancet Neurol 14, 291-301.

[17] Kaivorinne A-L, Krüger J, Kuivaniemi K, Tuominen H, Moilanen V, Majamaa K, Remes AM (2008) Role of MAPT mutations and haplotype in frontotemporal lobar degeneration in Northern Finland. BMC Neurol 17, 48.

[18] Krüger J, Kaivorinne A-L, Udd B, Majamaa K, Remes A-M (2009) Low prevalence of progranulin mutations in Finnish patients with frontotemporal lobar degeneration. Eur J Neurol 16, 27-30.

[19] Kaivorinne A-L, Krüger J, Udd B, Majamaa K, Remes AM (2010) Mutations in CHMP2B are not a cause of frontotemporal lobar degeneration in Finnish patients. Eur J Neurol 17, 1393-1395.

[20] Mesulam MM (2001) Primary progressive aphasia. Ann Neurol 49, 425-32.

[21] Fillenbaum GG, van Belle G, Morris JC, Mohs RC, Mirra SS, Davis PC, Tariot PN, Silverman JM, Clark CM, Wels-Bohmer KA, Heyman A (2008) Consortium to Establish a Registry for Alzheimer's Disease (CERAD): the first twenty years. Alzheimers Dement 4, 96-109.

[22] Sotaniemi M, Pulliainen V, Hokkanen L, Pirttilä T, Hallikainen I, Soininen H, Hänninen T: CERAD-neuropsychological battery in screening mild Alzheimer's disease (2012) Acta Neurol Scand 125,16-23.

[23] Hänninen T, Pulliainen V, Sotaniemi M, Hokkanen L, Salo J, Hietanen M, Pirttilä T, Pöyhönen M, Juva K, Remes A, Erkinjuntti T (2010) Muistisairauksien tiedonkäsittelymuutosten varhainen toteaminen uudistetulla CERAD-tehtäväsarjalla. Duodecim 126, 2013-2021.

[24] Majounie E, Renton AE, Mok K, Dopper EGP, Waite A, Rollinson S, Chiò A, Restagno G, Nicolaou N, Simon-Sanchez J, van Swieten JC, Abramzon Y, Johnson JO, Sendtner M, Pamphlett R, Orrell RW, Mead S, Sidle KC, Houlden H, Rohrer JD, Morrison KE, Pall H, Talbot K, Ansorge O, The Chromosome 9-ALS/FTD Consortium, The French research network on FTLD/FTLD/ALS, The ITALSGEN Consortium, Hernandez DG, Arepalli S, Sabatelli M, Mora G, Corbo M, Giannini F, Calvo A, Englund E, Borghero G, Floris GL, Remes AM, Laaksovirta H, McCluskey L, Trojanowski JQ, Van Deerlin VM, Schellenberg GD, Nalls MA, Drory VE, Lu CS, Yeh TH, Ishiura H, Takahashi Y, Tsuji S, Le Ber I, Brice A, Drepper C, Williams N, Kirby J, Shaw P, Hardy J, Tienari PJ, Heutink P, Morris HR, Pickering-Brown S, Traynor BJ (2012) Frequency of the C9orf72 hexanucleotide repeat expansion in patients with amyotrophic lateral sclerosis and frontotemporal dementia: a cross-sectional study. Lancet Neurol 11 323-330.

[25] Kertesz A, Ang LC, Jesso S, MacKinley J, Baker M, Brown P, Shoesmith C, Rademakers R, Finger EC (2013) Psychosis and hallucinations in frontotemporal dementia with the C9ORF72 mutation: a detailed clinical cohort. Cogn Behav Neurol 26, 146-154.

[26] Suhonen NM, Haanpää RM, Korhonen V, Jokelainen J, Pitkäniemi A, Heikkinen AL, Krüger J, Hartikainen P, Helisalmi S, Hiltunen M, Hänninen T, Remes AM (2017) 
Neuropsychological Profile in the C9ORF72 Associated Behavioral Variant Frontotemporal Dementia. J Alzheimers Dis 58, 479-489.

[27] Rohrer JD, Knight WD, Warren JE, Fox NC, Rossor MN, Warren JD (2008) Wordfinding difficulty: a clinical analysis of the progressive aphasias. Brain 131, 8-38.

[28] Kertesz A, Harciarek M (2014). Primary progressive aphasia. Scand J Psychol 55, 191201.

[29] Poole ML, Brodtmann A, Darby D, Vogel AP (2017) Motor Speech Phenotypes of Frontotemporal Dementia, Primary Progressive Aphasia, and Progressive Apraxia of Speech. J Speech Lang Hear Res 60, 897-911. 
Table 1. Demographics of the study participants.

\begin{tabular}{|c|c|c|c|c|}
\hline & $\begin{array}{l}\text { All patients } \\
\text { with } \\
\text { confirmed } \\
\text { C9orf72 status }\end{array}$ & C9orf72+ & C9orf72 - & p value \\
\hline $\mathrm{N}$ & 18 & 5 & 13 & \\
\hline Gender: male, N (\%) & $6(33.3 \%)$ & $2(40.0 \%)$ & $4(30.8 \%)$ & 1.000 \\
\hline Education $^{1}$ (years) & $\begin{array}{l}9-14 \\
\text { median } 12 \\
\text { IQR 5 }\end{array}$ & $\begin{array}{l}9-14 \\
\text { median } 12 \\
\text { IQR } 4\end{array}$ & $\begin{array}{l}9-14 \\
\text { median } 12 \\
\text { IQR 5 }\end{array}$ & 0.661 \\
\hline $\begin{array}{l}\text { Age at onset of symptoms } \\
\text { (years) }\end{array}$ & $\begin{array}{l}53.1-79.3 \\
\text { median } 66.3 \\
\text { IQR } 10.6\end{array}$ & $\begin{array}{l}62.2-78.1 \\
\text { median } 65.0 \\
\text { IQR } 11.3\end{array}$ & $\begin{array}{l}53.1-79.3 \\
\text { median } 67.7 \\
\text { IQR } 13.5\end{array}$ & 0.924 \\
\hline Age at diagnosis (years) & $\begin{array}{l}57.1-80.4 \\
\text { median } 68.0 \\
\text { IQR } 12.5\end{array}$ & $\begin{array}{l}63.1-79.7 \\
\text { median } 67.2 \\
\text { IQR } 11.6\end{array}$ & $\begin{array}{l}57.1-80.4 \\
\text { median } 68.3 \\
\text { IQR } 14.0\end{array}$ & 0.924 \\
\hline Age at death (years) & $\begin{array}{l}61.0-85.9 \\
\text { median } 75.3 \\
\text { IQR } 14.5 \\
(\mathrm{~N}=14)\end{array}$ & $\begin{array}{l}67.2-81.5 \\
\text { median } 68.6 \\
\text { IQR - } \\
(\mathrm{N}=3)\end{array}$ & $\begin{array}{l}61.0-85.3 \\
\text { median } 76.1 \\
\text { IQR } 14.1 \\
(\mathrm{~N}=11)\end{array}$ & 0.368 \\
\hline $\begin{array}{l}\text { Duration from the onset to } \\
\text { diagnosis (years) }\end{array}$ & $\begin{array}{l}0.3-5.2 \\
\text { median } 2.2 \\
\text { IQR } 2.0\end{array}$ & $\begin{array}{l}0.3-2.9 \\
\text { median } 2.2 \\
\text { IQR } 1.7\end{array}$ & $\begin{array}{l}0.7-5.2 \\
\text { median } 2.2 \\
\text { IQR } 3.0\end{array}$ & 0.566 \\
\hline $\begin{array}{l}\text { Duration from the onset to } \\
\text { death (years) }\end{array}$ & $\begin{array}{l}2.3-13.9 \\
\text { median } 5.4 \\
\text { IQR } 4.8\end{array}$ & $\begin{array}{l}3.4-5.0 \\
\text { median } 3.8 \\
\text { IQR - }\end{array}$ & $\begin{array}{l}2.3-13.9 \\
\text { median } 6.3 \\
\text { IQR } 4.0\end{array}$ & 0.170 \\
\hline
\end{tabular}

IQR = Interquartile Range. ${ }^{1}=$ Educational data was missing for two participants. $\mathrm{P}$ value refers to the significance between the $C 9$ orf 72 repeat expansion carrier $(C 9$ orf $72+)$ and noncarrier (C9orf72-) groups. 
Table 2. Clinical characteristics of the study participants.

\begin{tabular}{|c|c|c|c|c|}
\hline & $\begin{array}{l}\text { All patients } \\
\text { with } \\
\text { confirmed } \\
\text { C9orf } 72 \text { status }\end{array}$ & C9orf72+ & C9orf72 - & p value \\
\hline \multicolumn{5}{|l|}{$\begin{array}{l}\text { Imaging-supported } \\
\text { diagnosis }\end{array}$} \\
\hline NfvPPA, N (\%) & $16(88.9 \%)$ & $3(60.0 \%)$ & $13(100.0 \%)$ & 0.065 \\
\hline PPA-NOS, N (\%) & $2(11.1 \%)$ & $2(40.0 \%)$ & $0(0.0 \%)$ & 0.065 \\
\hline \multicolumn{5}{|l|}{$\begin{array}{l}\text { Clinical criteria for } \\
\text { nfvPPA }\end{array}$} \\
\hline $\begin{array}{l}\text { Apraxia of } \\
\text { speech, N (\%) }\end{array}$ & $12(66.7 \%)$ & $2(40.0 \%)$ & $10(76.9 \%)$ & 0.268 \\
\hline $\begin{array}{l}\text { Agrammatism, } \mathrm{N} \\
(\%)\end{array}$ & $4(22.2 \%)$ & $1(20.0 \%)$ & $3(23.1 \%)$ & 1.000 \\
\hline $\begin{array}{l}\text { Spared single- } \\
\text { word } \\
\text { comprehension, } \\
\mathrm{N}(\%)\end{array}$ & $18(100.0 \%)$ & $5(100.0 \%)$ & $13(100.0 \%)$ & - \\
\hline $\begin{array}{l}\text { Impaired } \\
\text { comprehension of } \\
\text { syntactically } \\
\text { complex } \\
\text { sentences, } \mathrm{N}(\%)\end{array}$ & $11(61.1 \%)$ & $3(60.0 \%)$ & $8(61.5 \%)$ & 1.000 \\
\hline $\begin{array}{l}\text { Spared object } \\
\text { knowledge, N } \\
(\%)\end{array}$ & $18(100.0 \%)$ & $5(100.0 \%)$ & $13(100.0 \%)$ & - \\
\hline \multicolumn{5}{|l|}{ First symptoms } \\
\hline $\begin{array}{l}\text { Memory } \\
\text { impairment, } \mathrm{N} \\
(\%)\end{array}$ & $4(22.2 \%)$ & $2(40.0 \%)$ & $2(15.4 \%)$ & 0.533 \\
\hline $\begin{array}{l}\text { Hallucinations, } \mathrm{N} \\
(\%)\end{array}$ & $1(5.6 \%)$ & $1(20.0 \%)$ & $0(0.0 \%)$ & 0.278 \\
\hline $\begin{array}{l}\text { Depression, } N \\
(\%)\end{array}$ & $1(5.6 \%)$ & $0(0.0 \%)$ & $1(7.7 \%)$ & 1.000 \\
\hline $\begin{array}{l}\text { Apathy or inertia, } \\
\mathrm{N}(\%)\end{array}$ & $1(5.6 \%)$ & $0(0.0 \%)$ & $1(7.7 \%)$ & 1.000 \\
\hline Fatigue, N (\%) & $2(11.1 \%)$ & $0(0.0 \%)$ & $2(15.4 \%)$ & 1.000 \\
\hline $\begin{array}{l}\text { Dizziness or } \\
\text { collapse, N }(\%)\end{array}$ & $3(16.7 \%)$ & $0(0.0 \%)$ & $3(23.1 \%)$ & 0.522 \\
\hline $\begin{array}{l}\text { Overall slowness, } \\
\mathrm{N}(\%)\end{array}$ & $1(5.6 \%)$ & $0(0.0 \%)$ & $1(7.7 \%)$ & 1.000 \\
\hline $\begin{array}{l}\text { Word-finding } \\
\text { difficulties, } \mathrm{N} \\
(\%)\end{array}$ & $7(38.9 \%)$ & $2(40.0 \%)$ & $5(38.5 \%)$ & 1.000 \\
\hline $\begin{array}{l}\text { Initial language } \\
\text { symptoms }\end{array}$ & & & & \\
\hline
\end{tabular}




\begin{tabular}{|c|c|c|c|c|}
\hline $\begin{array}{l}\text { Word finding } \\
\text { difficulties, } \mathrm{N} \\
(\%)\end{array}$ & $18(100.0 \%)$ & $5(100.0 \%)$ & $13(100.0 \%)$ & - \\
\hline $\begin{array}{l}\text { Slowness of } \\
\text { speech, N (\%) }\end{array}$ & $5(27.8 \%)$ & $0(0.0 \%)$ & $5(38.5 \%)$ & 0.249 \\
\hline $\begin{array}{l}\text { Impaired word } \\
\text { repetition, } \mathrm{N}(\%)\end{array}$ & $5(27.8 \%)$ & $0(0.0 \%)$ & $5(38.5 \%)$ & 0.249 \\
\hline $\begin{array}{l}\text { Poverty of } \\
\text { speech, N (\%) }\end{array}$ & $10(55.6 \%)$ & $2(40.0 \%)$ & $8(61.5 \%)$ & 0.608 \\
\hline $\begin{array}{l}\text { Impaired } \\
\text { comprehension, } \\
\mathrm{N}(\%)\end{array}$ & $11(61.1 \%)$ & $3(60.0 \%)$ & $8(61.5 \%)$ & 1.000 \\
\hline $\begin{array}{l}\text { Reading } \\
\text { difficulties, } \mathrm{N} \\
(\%)\end{array}$ & $6(33.3 \%)$ & $1(20.0 \%)$ & $5(38.5 \%)$ & 0.615 \\
\hline $\begin{array}{l}\text { Writing } \\
\text { difficulties, } \mathrm{N} \\
(\%)\end{array}$ & $6(33.3 \%)$ & $1(20.0 \%)$ & $5(38.5 \%)$ & 0.615 \\
\hline Dysarthria, N (\%) & $2(11.1 \%)$ & $1(20.0 \%)$ & $1(7.7 \%)$ & 0.490 \\
\hline Mutism, N (\%) & $1(5.6 \%)$ & $0(0.0 \%)$ & $1(7.7 \%)$ & 1.000 \\
\hline
\end{tabular}


Table 3. CERAD subtest scores of the study participants.

\begin{tabular}{lllll}
\hline & $\begin{array}{l}\text { All patients with } \\
\text { confirmed } \\
\text { C9orf72 status }\end{array}$ & C9orf72 + & C9orf72 - & $\begin{array}{l}\text { p } \\
\text { value }\end{array}$ \\
\hline $\begin{array}{l}\text { Verbal fluency, median } \\
\text { (IQR) N }\end{array}$ & $5.5(8.0) \mathrm{N}=14$ & $4.0(5.0) \mathrm{N}=5$ & $7.0(12.0) \mathrm{N}=9$ & 0.112 \\
\hline $\begin{array}{l}\text { Naming test, median } \\
\text { (IQR) N }\end{array}$ & $7.5(6.0) \mathrm{N}=14$ & $8.0(5.0) \mathrm{N}=5$ & $7.0(8.0) \mathrm{N}=9$ & 0.898 \\
\hline MMSE, median (IQR) & $19.0(8.0) \mathrm{N}=14$ & $16.0(11.0) \mathrm{N}=5$ & $21.0(7.0) \mathrm{N}=9$ & 0.147 \\
\hline $\begin{array}{l}\text { Word list learning, } \\
\text { median (IQR) N }\end{array}$ & $9.0(5.0) \mathrm{N}=11$ & $9.0(14.0) \mathrm{N}=4$ & $9.0(5.0) \mathrm{N}=7$ & 1.000 \\
\hline $\begin{array}{l}\text { Constructional praxis, } \\
\text { median (IQR) N }\end{array}$ & $8.0(3.0) \mathrm{N}=11$ & $8.0(2.0) \mathrm{N}=4$ & $9.0(3.0) \mathrm{N}=7$ & 0.788 \\
\hline $\begin{array}{l}\text { Word list delayed } \\
\text { recall, median (IQR) N }\end{array}$ & $3.0(3.0) \mathrm{N}=11$ & $1.5(6.0) \mathrm{N}=4$ & $3.0(1.0) \mathrm{N}=7$ & 0.315 \\
\hline $\begin{array}{l}\text { Word list delayed recall } \\
\%, \text { median (IQR) N }\end{array}$ & $66.0(38.0) \mathrm{N}=11$ & $69.0(85.0) \mathrm{N}=4$ & $66.0(30.0) \mathrm{N}=7$ & 1.000 \\
\hline $\begin{array}{l}\text { Word list recognition } \\
\%, \text { median (IQR) N }\end{array}$ & $75.0(40.0) \mathrm{N}=11$ & $60.0(80.0) \mathrm{N}=4$ & $80.0(25.0) \mathrm{N}=7$ & 0.315 \\
\hline $\begin{array}{l}\text { Constructional praxis } \\
\text { delayed, median (IQR) }\end{array}$ & $6.0(6.0) \mathrm{N}=9$ & $7.0(-) \mathrm{N}=3$ & $5.0(8.0) \mathrm{N}=6$ & 0.714 \\
$\mathrm{~N}$ & & & & \\
\hline $\begin{array}{l}\text { Constructional praxis } \\
\text { delayed \%, median } \\
\text { (IQR) N }\end{array}$ & $62.0(74.0) \mathrm{N}=10$ & $56.5(76.0) \mathrm{N}=4$ & $62.0(75.0) \mathrm{N}=6$ & 0.610 \\
\hline $\begin{array}{l}\text { Clock drawing, median } \\
\text { (IQR) N }\end{array}$ & $2.5(2.0) \mathrm{N}=9$ & $3.0(3.0) \mathrm{N}=4$ & $2.0(3.0) \mathrm{N}=5$ & 0.905 \\
\hline
\end{tabular}

$\mathrm{IQR}=$ Interquartile Range. $\mathrm{P}$ value refers to the significance between the C9orf72 repeat expansion carrier $(C 9$ orf $72+)$ and non-carrier (C9orf72-) groups. 